and Rutter W. J.: Changes in the frequency of specific transcripts during development of the pancreas. J. Biol. Chem., 252: 7391 (1977).

9. Kahn, A., Cottreau, D., Daegelen, D., and Dreyfus, J. C.: Cell-free translation of messenger RNAs from adult and fetal human muscle. Eur. J. Biochem., 116 : 7 (1981).

10. Laemmli, U. K.: Cleavage of structural proteins during the assembly of the head of bacteriophage T4. Nature, 227: 680 (1970).

11. Pelham, H. R. B. and Jackson, R. J.: An efficient mRNA-dependent translation system from reticulocyte lysates. Eur. J. Biochem., 67: 247 (1976)
12. Proux, D. and Dreyfus, J. C.: Phosphorylase isoenzymes in tissues: prevalence of the liver type in man. Clin. Chim. Acta., 48: 167 (1973).

13. The authors are thankful to Dr. Georges Schapira, Dr. Jean Frézal and Dr. Lenny Groopman for their helpful discussion.

14. Requests for reprints should be addressed to: Dr. Axel Kahn, Institut de Pathologie Moleculaire, CHU Cochin, Rue du Fbg St. Jacques, 75014 Paris Cedex 14. France.

15. Received for publication June 17, 1981

16. Accepted for publication September 29. 1981

Copyright $\odot 1982$ International Pediatric Research Foundation, Inc.

0031-3998/82/1605-0335\$02.00/0

Printed in U.S.A.

\title{
ANNOUNCEMENT
}

\section{XIVTH MEETING OF THE INTERNATIONAL SOCIETY FOR PEDIATRIC ONCOLOGY (SIOP)}

BERN, SWITZERLAND, SEPTEMBER 21-25, 1982

\author{
Main Theme: NEW MODES OF THERAPY AND SUPPORTIVE CARE \\ -Immune Modulation \\ -Monoclonal Antibodies: Clinical Applications \\ -Bone Marrow Transplantation \\ -Infection and Nutrition \\ -New Modes in Surgery \\ -New Modes in Radiooncology \\ Reports on Current Trials \\ Pathologists Meeting \\ Language: \\ English \\ Place: \\ Department of Pediatrics, Inselspital, 3010 Bern, Switzerland \\ Information: \\ Hans P. Wagner, M.D. \\ c/o SPOG \\ Institute for Clinical and Experimental Cancer Research \\ Tiefenauspital \\ 3004 Bern, Switzerland
}

